\title{
Antarctic ice sheet fertilises the Southern Ocean
}

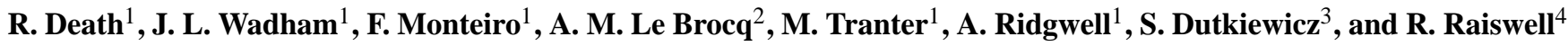 \\ ${ }^{1}$ School of Geographical Sciences, University of Bristol, BS81SS, UK \\ ${ }^{2}$ Geography, College of Life and Environmental Sciences, University of Exeter, EX4 4RJ, UK \\ ${ }^{3}$ Department of Earth, Atmosphere and Planetary Sciences, Massachusetts Institute of Technology, MA 02139, USA \\ ${ }^{4}$ School of Earth and Environment, University of Leeds, LS2 9JT, UK
}

Correspondence to: J. L. Wadham (j.l.wadham@bris.ac.uk)

Received: 7 June 2013 - Published in Biogeosciences Discuss.: 30 July 2013

Revised: 19 March 2014 - Accepted: 25 March 2014 - Published: 19 May 2014

\begin{abstract}
Southern Ocean (SO) marine primary productivity (PP) is strongly influenced by the availability of iron in surface waters, which is thought to exert a significant control upon atmospheric $\mathrm{CO}_{2}$ concentrations on glacial/interglacial timescales. The zone bordering the Antarctic Ice Sheet exhibits high PP and seasonal plankton blooms in response to light and variations in iron availability. The sources of iron stimulating elevated SO PP are in debate. Established contributors include dust, coastal sediments/upwelling, icebergs and sea ice. Subglacial meltwater exported at the ice margin is a more recent suggestion, arising from intense iron cycling beneath the ice sheet. Icebergs and subglacial meltwater may supply a large amount of bioavailable iron to the SO, estimated in this study at $0.07-0.2 \mathrm{Tg} \mathrm{yr}^{-1}$. Here we apply the MIT global ocean model (Follows et al., 2007) to determine the potential impact of this level of iron export from the ice sheet upon SO PP. The export of iron from the ice sheet raises modelled SO PP by up to $40 \%$, and provides one plausible explanation for seasonally very high in situ measurements of PP in the near-coastal zone. The impact on SO PP is greatest in coastal regions, which are also areas of high measured marine PP. These results suggest that the export of Antarctic runoff and icebergs may have an important impact on SO PP and should be included in future biogeochemical modelling.
\end{abstract}

\section{Introduction}

Primary production in the Southern Ocean (SO) accounts for 5-10\% of total global oceanic primary production (Moore and Abbott, 2000; Arrigo et al., 2008) and has an important impact on climate via its regulatory effect upon atmospheric
$\mathrm{CO}_{2}$ concentrations (Sigman and Boyle, 2000). The $\mathrm{SO}$ is a high-nutrient-low-chlorophyll (HNLC) region, where iron is the main limiting nutrient, preventing phytoplankton from using the available $\mathrm{N}$ and $\mathrm{P}$ (Martin, 1990). Hence, changes in the supply of iron are hypothesised to cause variations in SO PP, and hence $\mathrm{CO}_{2}$ drawdown (Sarmiento and Orr, 1991). Well-established iron sources include coastal sediments/upwelling (Tagliabue et al., 2009), sea ice (Edwards and Sedwick, 2001) and dust (Martin, 1990; Jickells et al., 2005), and more recently, iceberg-rafted debris (Raiswell et al., 2008; Raiswell and Canfield, 2012). Subglacial meltwater discharged from the ice sheet has received comparatively little attention to date (Statham et al., 2008; Wadham et al., 2013). The impacts of both these glacial sources of iron upon SO PP have not yet been quantified and form the focus of this paper. The significance of glacial iron sources is heightened by predictions of rising meltwater and iceberg fluxes in future decades (Vaughan, 2006; Pritchard et al., 2012).

Debris entombed in icebergs and meltwater from beneath glaciers has been shown to be rich in bioavailable iron, arising from intense iron cycling in subglacial environments (Statham et al., 2008; Raiswell et al., 2009; Wadham et al., 2010; Bhatia et al., 2013). Sulfide oxidation produces Fe(III) (in the form of $\mathrm{Fe}(\mathrm{OH})_{3}$ ) under oxic conditions and $\mathrm{Fe}(\mathrm{II})$ by microbial mediation under anoxic conditions (Eqs. (1) and (2), respectively) (Wadham et al., 2010). It is enhanced by the continual exposure of fresh and reactive sulfide minerals by glacial erosion:

$$
\begin{aligned}
& 4 \mathrm{FeS}_{2}+15 \mathrm{O}_{2}+14 \mathrm{H}_{2} \mathrm{O} \Rightarrow 8 \mathrm{SO}_{4}^{2}+\mathbf{4 F e}(\mathrm{OH})_{3}+16 \mathrm{H}^{+} \\
& \mathrm{FeS}_{2}+14 \mathrm{Fe}^{3+}+8 \mathrm{H}_{2} \mathrm{O} \Rightarrow 2 \mathrm{SO}_{4}^{2-}+\mathbf{1 5} \mathrm{Fe}^{2+}+16 \mathrm{H}^{+}
\end{aligned}
$$


Table 1. Annual iron fluxes modelled in this paper for aeolian dust, icebergs and subglacial meltwater and in comparison to previously calculated values for these and other hypothesised iron sources to the Southern Ocean.

\begin{tabular}{ll}
\hline Fe Source & Flux $\left(\mathrm{Tg} \mathrm{yr}^{-1}\right)$ \\
\hline Input to model & \\
Antarctic subglacial meltwater* & $0.009-0.090$ \\
Icebergs (aqueous and nanoparticulate) & 0.065 \\
Aeolian dust & 0.075 \\
& \\
Previously calculated fluxes & \\
Icebergs (aqueous); Raiswell et al., 2008 & $0.001-0.005$ \\
Icebergs (aqueous+nanoparticulate); Raiswell et al., 2008 & $0.06-0.120$ \\
Sea ice; Edwards and Sedwick, 2001 & $3 \times 10^{-4}$ \\
Aeolian dust; Raiswell et al,. 2008 & $0.01-0.130$ \\
Benthic recycling from sediments; Raiswell and Canfield, 2012 & $0.013-0.032$ \\
Hydrothermal iron; Taglaibue et al., 2010 & 0.021 \\
\hline
\end{tabular}

* This assumes that all the SGM Fe flux is delivered to the MIT ocean cell adjacent to the coast.

Subglacial meltwaters are generated at the bed of the ice sheet by geothermal heating of basal ice layers (Pattyn, 2010). They are driven toward the margin via the dynamic filling and draining of subglacial lakes and/or via subglacial rivers (Fricker et al., 2007; Wingham et al., 2006), where they are exported via channels or as groundwater (Supplement 2). Solute fluxes associated with this water export are likely to be high and of a similar magnitude to those from some of the planet's largest rivers (Wadham et al., 2010). We would expect iron concentrations in subglacial meltwaters (SGM-Fe, i.e. aqueous+nanoparticulate+some colloidal $\mathrm{Fe},<0.4 \mu \mathrm{m}$ ) to be at the higher end of the reported range for glacial runoff (e.g. $\mu \mathrm{M} \mathrm{Fe}$, Supplement Table 1), consistent with the prevailing elevated rock:water ratios, prolonged water residence times and anoxic conditions. In support of this are high concentrations of sulfate ions in porewaters from the Kamb and Bindschadler ice streams (West Antarctica) and frozen lake ice from subglacial Lake Vostok (East Antarctica) (Skidmore et al., 2010; Christner et al., 2006). The highest dissolved iron concentrations in Antarctic coastal waters have also recently been measured in the Pine Island Polynya, thought to be associated with the release of iron-rich meltwater from Pine Island Glacier (Gerringa et al., 2012). Glacial ice and sea ice are relatively dilute in comparison (nM Fe, Supplement Table 1). We calculate that the potential iron export in subglacial meltwater is $\sim 0.009-0.09 \mathrm{Tg} \mathrm{a}^{-1}$ (where SGM$\mathrm{Fe}$ concentrations $=3$ and $30 \mu \mathrm{M}$, respectively. We note that this assumes a $100 \%$ export efficiency from the ice margin to coastal waters for SGM iron, since the proportion of iron which is removed from the water column beneath ice shelves is unknown. This flux of SGM iron is of a similar order of magnitude to $\mathrm{Fe}$ sources from icebergs, aeolian dust (Raiswell et al., 2008) and benthic recycling from sediments (Raiswell and Canfield, 2012; Table 1).

The potential impact of iron in iceberg-rafted debris upon SO PP has received greater consideration in the litera- ture (Raiswell et al., 2009; Schwarz and Schodlok, 2009; Smith et al., 2011). Nanoparticulate iron oxyhydroxide is produced originally by sulfide oxidation in regelation waters and by the diffusion and subsequent oxidation of dissolved $\mathrm{Fe}(\mathrm{II}) . \mathrm{Fe}(\mathrm{II})$ is generated under anoxic conditions in subglacial sediment porewaters which on entry into oxic micro-environments at the ice-bed interface rapidly oxidise to Fe(III) (Raiswell et al., 2009). This nanoparticulate iron is bioavailable and is preserved within the debris-rich ice sections of icebergs which may be exported large distances across the SO (Raiswell et al., 2008). It has been shown by one modelling study to have an impact on SO Chlorophyll $a$ concentrations that substantially exceeds that of aeolian dust (Lancelot et al., 2009).

\section{Methods}

\subsection{Numerical model}

We evaluate the potential impact of iron fluxes via icebergs and subglacial meltwater on SO PP for the present day using the MIT global ocean model (Follows et al., 2007; Monteiro et al., 2010), and compare these impacts with those from aeolian dust iron inputs. The MIT global ocean biogeochemical/ecological has a $1^{\circ} \times 1^{\circ}$ horizontal resolution and 23 vertical levels, and uses the ECCO-GODAE state estimates of ocean circulation (Wunsch and Heimbach, 2007). We initialised the model with nutrient fields of WOA01 (Conkright et al., 2002) for consistency with previous simulations (Monteiro et al., 2010). The model simulations are run for 10 years, which is sufficient to attain surface iron steady state in the SO whilst maintaining other nutrient fields close to observations. The modelled ocean ecosystem represents a range of phytoplankton and two zooplankton types. The ecosystem structure of the modelled phytoplankton is self-assembled 
from an initialised random population of 78 phytoplankton which includes different types of diatoms, nitrogen fixers, other small cyanobacteria and large eukaryotes (Monteiro et al., 2010). In addition to phytoplankton activity and grazing, the model accounts explicitly for ocean dynamics of Dissolved Organic matter (DOM) and Particulate Organic Matter (POM). The ocean biogeochemical cycles of phosphorus, nitrogen, silica and iron are represented in the model.

Within the model framework, geochemical and biological processes interact via the uptake of nutrients, phytoplankton growth and decay and remineralisation of organic matter at depth. Of particular interest to this study is the manner in which the model deals with iron cycling and how the modelled surface ocean phytoplankton community responds to changes in iron bioavailability. The parameterisation of the iron cycle within the MIT model is prescribed (Parekh et al., 2004, 2005), with iron existing in a "free" state or complexed to an organic ligand with binding strength of $K_{\mathrm{FeL}}\left(2 \times 10^{5}\right.$ $\left.\mu \mathrm{M}^{-1}\right)$. The amount of iron that exists in an organic complex is determined by the total ligand concentration $(1 \mathrm{nM})$ and the stability of the ligand complex $\left(K_{\mathrm{FeL}}\right)$. Removal of iron occurs either via biological uptake, which is described in Dutkiewicz et al. (2005) or by scavenging of free iron to particles, with a scavenging rate of $1.1 \times 10^{-3} \mathrm{~d}^{-1}$. The rate at which iron is removed from the surface ocean waters and transported to depth is controlled by the sinking rate of particulate organic matter (POM) $\left(10 \mathrm{~m} \mathrm{~d}^{-1}\right)$. The rate at which dissolved iron is returned to the water column through remineralisation depends on whether it is in an organic or nanoparticulate form. The organic matter remineralisation rate is $0.01 \mathrm{~d}^{-1}$, while the particulate matter rate is $0.02 \mathrm{~d}^{-1}$. Therefore, the vertical profile of dissolved iron in the water column is determined by the balance between the rate of iron acquisition and mineralisation versus the rate of iron losses via biological uptake and/or scavenging.

\subsection{Iron input fluxes to the model}

We model five scenarios for iron inputs to the SO (see Table 1): (a) dust-only; (b) icebergs and dust; (c) subglacial meltwater and dust (where $[\mathrm{Fe}]=3 \mu \mathrm{M}$ ); (d) subglacial meltwater and dust (where $[\mathrm{Fe}]=30 \mu \mathrm{M}$ ) (Supplement Table 1) and (e) subglacial meltwater, icebergs and dust (where $[\mathrm{Fe}]=3 \mu \mathrm{M}]$ ). We assume that the $\mathrm{Fe}$ input via subglacial meltwater is in the dissolved phase. While we acknowledge that other iron sources may be important within the SO, for example benthic recycling from sediments (Lancelot et al., 2009; Tagliabue et al., 2010; Raiswell and Canfield, 2012) as well as hydrothermal contributions (Tagliabue et al., 2010, 2014), we do not include these sources within the model due to uncertainties regarding their parameterisation at present. However, we acknowledge that additional iron sources would increase primary production compared to our existing model scenarios. Hence, we consider the latter to yield minimum estimates of SO primary pro- ductivity. The following sections detail how iron fluxes from dust, subglacial meltwater and icebergs are calculated and input to the model as forcing fields for primary productivity of the SO. Other glacially sourced nutrient inputs (e.g. Si) are not included in these scenarios.

\subsubsection{Dust fluxes}

The standard run uses the MIT model, where the aeolian dust flux (Mahowald et al., 2005) is the only source of iron to the ocean. The solubility of dust iron is set in the MIT model at $2.0 \%$ (considered a higher estimate; Boyd et al., 2010) which is assumed to be bioavailable to phytoplankton.

\subsubsection{Subglacial meltwater Fe fluxes}

Meltwater beneath the ice sheet is generated using the GLIMMER model (Rutt et al., 2009), with the modifications described in Le Brocq et al. (2011). Meltwaters are supplied from the ice sheet to the coastal cells around the ice sheet perimeter using a flow routing scheme that apportions the flow downstream based on the surrounding local slope angle. The slopes are derived from the basal topography provided by the BEDMAP data set (Lythe et al., 2001). The total subglacial meltwater output from the Antarctic Ice Sheet calculated using this method is $52.8 \mathrm{Gt} \mathrm{a}^{-1}$, which is similar to a previous estimate of $65 \mathrm{Gt} \mathrm{a}^{-1}$ (Pattyn, 2010). The difference between these two estimates arises because the GLIMMER method applies a constant geothermal heat flux (GHF), in contrast to Pattyn (2010) who uses a spatially distributed field for GHF. The fluxes to the coastal cells are summed onto a latitude/longitude grid which is concordant with the MIT model grid. In the current configuration the meltwater is released to the surface ocean layer of the MIT model. We are aware that these waters are more likely to be released from the base of the ice sheet, which may be at some depth. However, since this water will be fresh compared to seawater, it is likely to upwell close to the coast and in $<1$ grid cell $(100 \mathrm{~km})$ as has been indicated by recent work (Le Brocq et al., 2013; Gladish et al., 2012). Hence, assuming water input within the surface layer of the coastal grid cells of the MIT model is a reasonable approximation of the real-world situation. We recognise that we have not allowed for loss of iron through scavenging and mixing during this upwelling, and hence, the iron delivered to the surface may be a maximum estimate in each scenario.

Iron fluxes in subglacial meltwater are calculated as the product of the water input (in $\mathrm{m}^{3}$ ) within each coastal cell and a representative iron concentration value. We employ lower and upper boundary concentrations (in this case 3 or $30 \mu \mathrm{M}$ : see Supplement 1) based upon field observations of typical iron concentrations in subglacial meltwaters (see Supplement Table 1). These iron fluxes associated with subglacial meltwater are added to the aeolian dust iron input field deposition, and used in combination as iron input forcing to the model. 


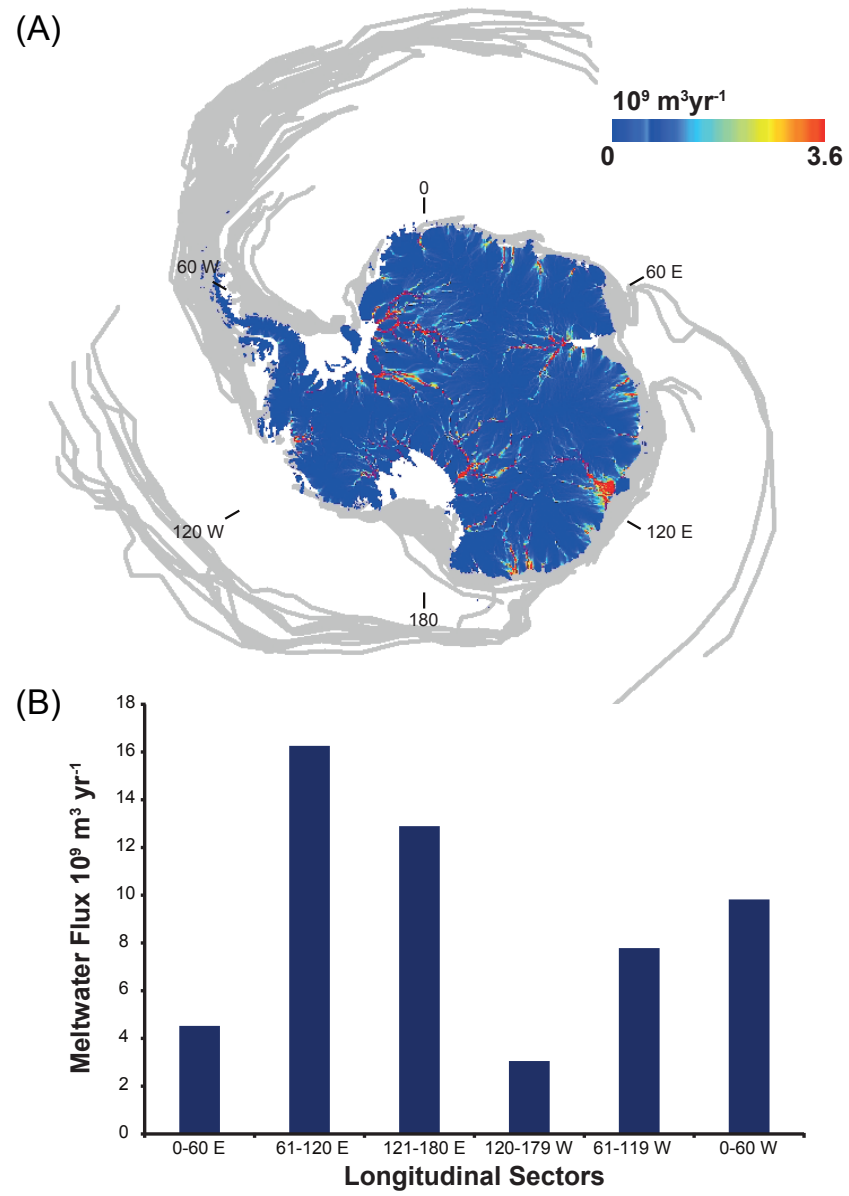

Figure 1. (a) Distribution of ice-sheet-derived iron fluxes showing modelled subglacial meltwater fluxes and iceberg tracks from the Antarctic Ice Sheet. Both of these ice-sheet-derived mass flux distributions are controlled principally by the location of major ice stream complexes and ocean circulation. (b) Regionally integrated coastal subglacial meltwater fluxes indicating which regions around Antarctica are most influenced by subglacial meltwater input.

\subsubsection{Iceberg Fe fluxes}

The release of meltwater from icebergs accounts for 60-80\% of the freshwater flux from Antarctica (Martin and Adcroft, 2010). The calving locations, number and size of icebergs are calculated from balance fluxes along the coastal margins. The iceberg flux is calculated at a $1^{\circ} \times 1^{\circ}$ resolution to match the resolution of the MIT model. A statistical distribution (Gladstone et al., 2001) is used to partition this iceberg mass flux leaving the coast into ten different size classes. This allows us to generate the number of icebergs within each size class for each coastal cell. We employ an iceberg model (Bigg et al., 1997) previously applied to the SO (Gladstone et al., 2001) to model the iceberg flow paths. The modelled iceberg tracks compare well with observations, and are discussed in Supplementary Information (Supplement Fig. 1).
Table 2. Summary statistics (mean, RMS, standard deviation) for observed (Tagliabue et al., 2012) and modelled surface ocean (0$100 \mathrm{~m}$ ) iron concentrations.

\begin{tabular}{lrrr}
\hline Scenario & $\begin{array}{r}\text { Mean } \\
(\mathrm{nM})\end{array}$ & $\begin{array}{r}\text { Standard } \\
\text { Deviation }\end{array}$ & RMS \\
\hline Observations & 0.47 & 0.66 & $\mathrm{n} / \mathrm{a}$ \\
A - Dust only & 0.26 & 0.06 & 0.65 \\
B - Icebergs & 0.60 & 0.70 & 0.87 \\
C - SGM $(3 \mu \mathrm{M})$ & 0.35 & 0.14 & 0.63 \\
D - SGM $(30 \mu \mathrm{M})$ & 1.05 & 0.89 & 0.90 \\
E - Icebergs+SGM $(3 \mu \mathrm{M})$ & 0.81 & 0.92 & 1.03 \\
\hline
\end{tabular}

The bioavailable iron released from melting icebergs in the model is based upon a number of assumptions since there is little observational data of the sediment loading within icebergs from Antarctica. We assume that the sediment distribution within icebergs comprises a basal debris layer (the size of which has been reported between 1 to $10 \mathrm{~m}$; Anderson et al., 1980; Syvitski et al., 1996), with the remainder of the iceberg containing a sediment concentration that reflects the aeolian dust flux to the Antarctic Ice Sheet. The dust flux is derived from observations of dust deposition over Antarctica (Mahowald et al., 2009) $\left(0.01 \mathrm{~g} \mathrm{~m}^{-2} \mathrm{yr}^{-1}\right)$. For this study we assume that the icebergs have a debris layer depth of $5 \mathrm{~m}$, which is approximately the median of values reported in the literature (Anderson et al., 1980; Syvitski et al., 1996; Dowdeswell et al., 1995). The sediment content of the icebergs is estimated at $5 \%$. Field observations from Antarctic icebergs (Anderson et al., 1980) suggest a debris content of between 4 to $8 \%$ by weight. For comparison, samples from 20 icebergs around Spitsbergen contained a range of sediment concentrations ( 0.02 to $28 \%$ by weight) within the basal debris layer (Dowdeswell and Dowdeswell, 1989). Photographic evidence suggests that icebergs may also carry their sediment in englacial layers (Raiswell, 2011) which is not accounted for in the current model configuration. Neglecting the englacial component of iceberg-rafted debris will only serve to minimise the quantity and spatial distribution of iron delivery from icebergs to the SO, making model results conservative.

The form and reactivity of the iron within the glacial debris and the dust fraction is also considered in order to model the fate of the iron held within icebergs. For the ice containing only aeolian dust, we assume the same solubility (2\%) as the direct dust flux to the ocean (see Sect. 2.2.1). The reactivity of the debris in the basal layer is calculated as follows. There are few direct measurements of the iron content of free-drifting icebergs (Shaw et al., 2011), but estimates exist for sediment in grounded icebergs in Antarctica (Raiswell et al., 2008). Nanoparticles of iron oxyhydroxides are found within the iceberg-hosted sediment in significant quantities, and the iron content in the reactive phases of ferrihydrite and nanogoethite is $0.10 \pm 0.11 \%$. We assume that 

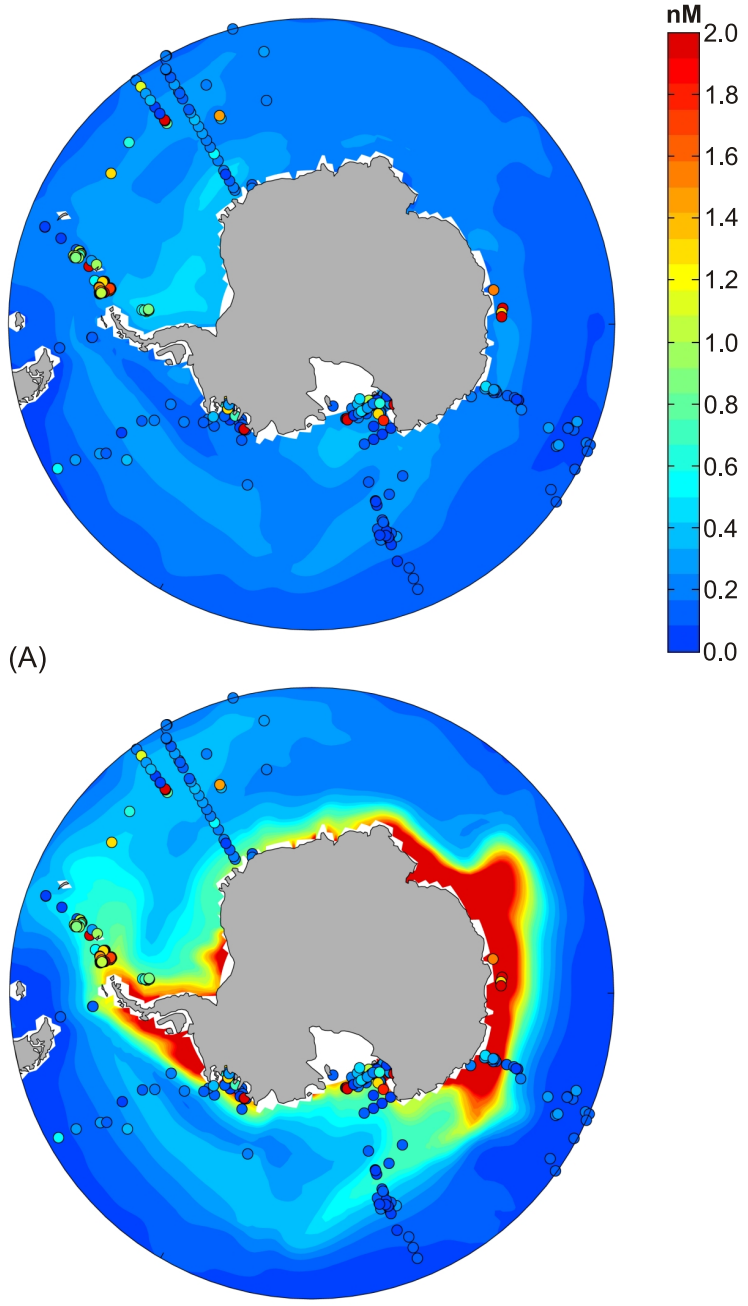

(B)

Figure 2. The geographical distribution of the impact of iron inputs upon modelled surface $(0-100 \mathrm{~m})$ ocean iron concentrations is shown for (A) Scenario A (dust only) and (B) Scenario E (dust, subglacial meltwater (where $[\mathrm{Fe}]=3 \mu \mathrm{M}$ ) and icebergs). Observed surface ocean iron concentrations are shown as coloured circles, and are derived from (Tagliabue et al., 2012) with data from the Amundsen Sea from (Gerringa et al., 2012).

the proportion of this iron that is bioavailable is $10 \%$, and hence, that $0.01 \%$ of the basal sediment is bioavailable iron (Raiswell et al., 2008). The bioavailable iron that is released by each iceberg into the MIT ocean grid cell is summed and overlaid onto the dust deposition field to produce an overall map of iron input to the SO from icebergs and aerosol dust input.

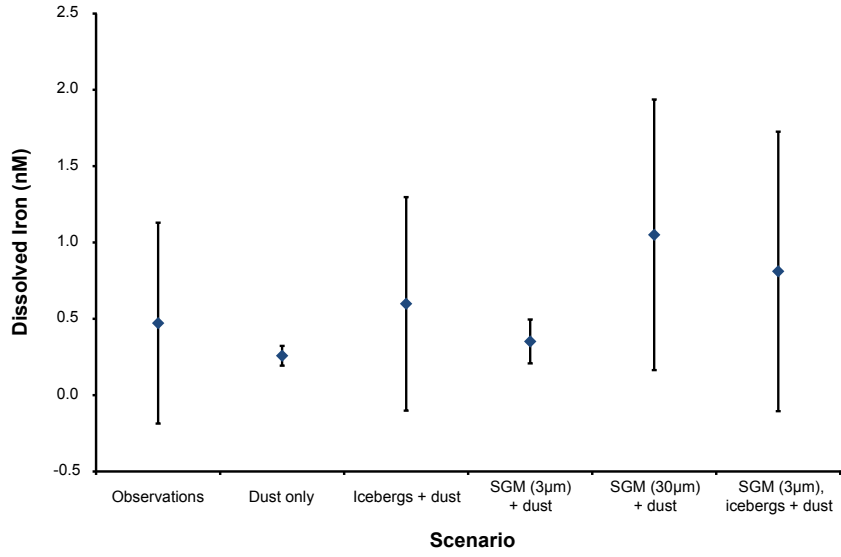

Figure 3. Summary statistics (mean and standard deviation) for observed (Tagliabue et al., 2012) and modelled surface ocean (0$100 \mathrm{~m}$ ) iron concentrations, illustrating the differences between the modelled scenarios.

\section{Results and discussion}

\subsection{Modelled iron fluxes to the Southern Ocean}

Iron fluxes in subglacial meltwaters are distributed along the Antarctic coast, in accordance with the pattern of subglacial water export (Fig. 1a, Supplement 3), with the highest total fluxes around the East Antarctic margin (Fig. 1b). Icebergderived iron fluxes follow iceberg tracks (Fig. 1a), which also correspond approximately to spatial patterns of subglacial meltwater release, since ice stream dynamics control the fluxes of both iron sources. Modelled mean annual surface ocean iron concentrations are enhanced in zones of high subglacial meltwater and iceberg iron input, most prominently around the coast (Fig. 2, Supplement Fig. 2). Many of these zones of iron enhancement in the model correspond with areas of high measured iron concentrations, such as in the Ross Sea (Moore and Braucher, 2008) and Amundsen Sea (Gerringa et al., 2012) (Fig. 2a and b, Supplement Fig. 2). Dust fluxes of iron (Fig. 2a) cannot explain some of the high measured iron concentrations in surface coastal ocean waters pointing towards an additional iron source. One possible source for this iron is the ice sheet.

A more quantitative analysis of these results is presented in Fig. 3, with the data provided in Table 2. Because of the limitations of the data, we are not able to make a judgment that any single model scenario does a better job. However, the magnitude and variability of iron concentrations in the Southern Ocean are best matched by those scenarios which include additional iron inputs, as opposed to the dust-only run. The latter shows a very limited range and generally lower iron concentrations in surface ocean waters than those with a glacial iron source as prescribed in scenarios B, D and E (Table 2). 


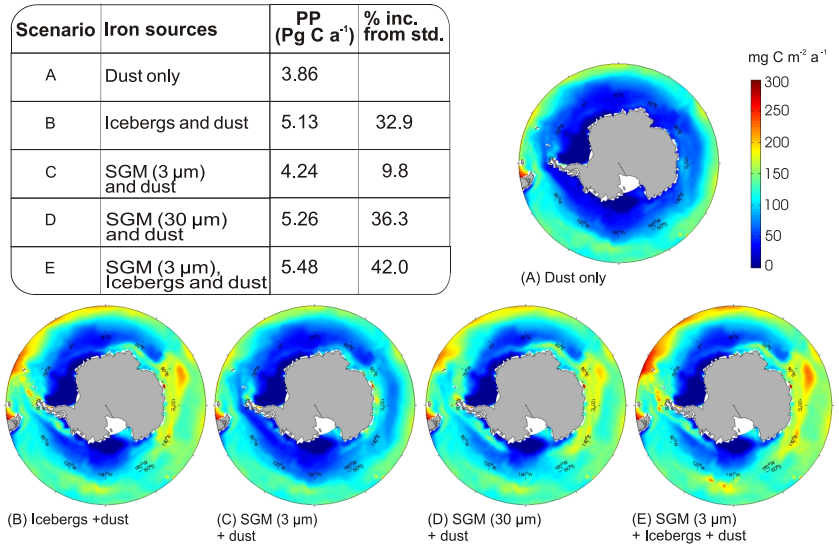

Figure 4. Modelled sensitivity of annual primary productivity of the Southern Ocean to external iron inputs. Tabulated total PP generated by the different model scenarios and polar stereographic images of annual primary productivity for model scenarios, (A) aeolian dust, (B) icebergs, (C) subglacial meltwater, SMW, where $[\mathrm{Fe}]=3 \mu \mathrm{M}$, (D) SMW, where $[\mathrm{Fe}]=30 \mu \mathrm{M}$ and (E) aeolian dust + icebergs + SMW (where $[\mathrm{Fe}]=3 \mu \mathrm{M}$ ).

\subsection{Impact upon SO wide primary productivity}

Iceberg, subglacial meltwater (B-D) and combined iceberg/meltwater (E) iron inputs have a pronounced (10-40\%) impact on total Southern Ocean PP (Fig. 4) above that generated by dust-only simulations (A). A fourfold difference between SO PP enhancement associated with subglacial meltwater with an $[\mathrm{Fe}]$ of $3 \mu \mathrm{M}$ and $30 \mu \mathrm{M}$ also indicates a sensitivity to meltwater Fe concentrations. The geographical distribution of ice sheet iron impacts on ocean-wide SO PP reflect (a) the location of iron inputs from major ice streams or iceberg melting, (b) the redistribution of this iron via ocean circulation and (c) the geographical distribution of SO iron limitation. Many regions of elevated mean annual PP in both subglacial meltwater and iceberg iron input scenarios (Fig. 4) match to zones of high runoff or iceberg calving fluxes around the Antarctic margin (Fig. 1). These include large parts of East Antarctica, such as Prydz Bay, and the Ross, Weddell and Amundsen Seas, which are all areas of high measured summer PP (Demidov et al., 2007; Smith and Nelson, 1990; Smith et al., 1996; Gerringa et al., 2012). The similarities in the spatial distribution of annual PP enhancement in iceberg and subglacial meltwater flux simulations (Fig. 4) arises from the fact that the surface ocean currents that transport the icebergs also convey the subglacial meltwater away from the ice margin. Northward advection of ice-sheet-derived iron by ocean currents is evident from the elevated PP values at lower latitudes relative to dust sources alone, with an effect that extends as far as $50^{\circ} \mathrm{S}$ in scenarios B-E (Fig. 4). For example, along the western margin of the Antarctic Peninsula (B-E) where runoff fluxes are low and the enhanced PP is stimulated by glacially derived Fe

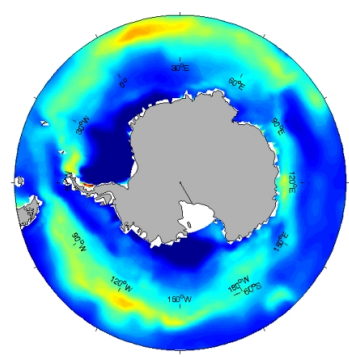

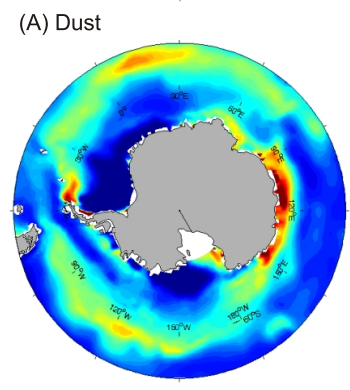

(C) SGM $3 \mu \mathrm{m}+$ dust

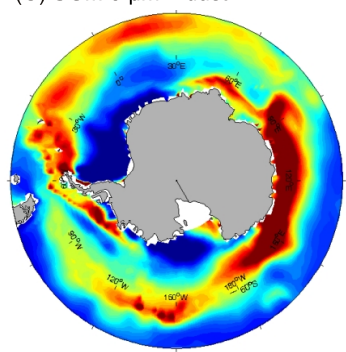

(E) SGM $(3 \mu \mathrm{m})+$ lcebergs + dust

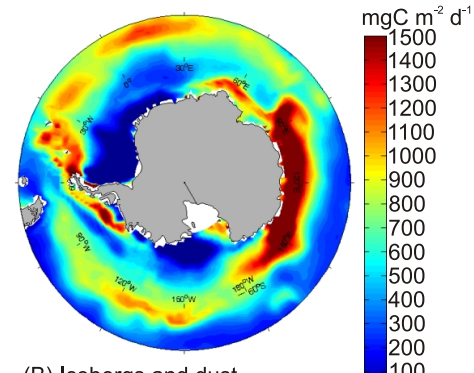

(B) lcebergs and dust

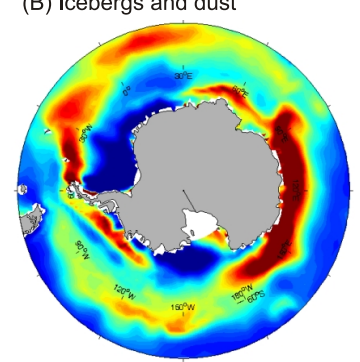

(D) SGM $30 \mu \mathrm{m}+$ dust
Figure 5. Modelled mean seasonal primary productivity (December, January, February) of the Southern Ocean in response to dust and glacial iron inputs for model scenarios (A) aeolian dust, (B) icebergs, (C) SMW, where $[\mathrm{Fe}]=3 \mu \mathrm{M}$, (D) SMW, where $[\mathrm{Fe}]=30 \mu \mathrm{M}$ and (E) Aeolian dust + icebergs + SMW (where $[\mathrm{Fe}]=3 \mu \mathrm{M})$.

advected north from the Ross Sea and Amundsen Sea. These results highlight the importance of ocean circulation in promoting iron fertilisation from subglacial runoff and icebergs over a large proportion of the SO.

\subsection{Impact upon coastal primary productivity}

In addition to ocean-wide effects on SO PP, glacial sources of iron also have the potential to drive strong enhancement of PP in the near-coastal zone in spring/summer. Spring blooms, where primary productivity attains values of the order of $10^{3} \mathrm{mg} \mathrm{C} \mathrm{m}^{-2} \mathrm{~d}^{-1}$, are commonly measured at the ice edge in early summer (Arrigo et al., 2008) along the Antarctic Peninsula (Smith et al., 1998) in the Ross Sea (Smith et al., 1996), Weddell Sea (Smith and Nelson, 1990), Amundsen Sea (Gerringa et al., 2012) and Prydz Bay (Westwood et al., 2010). This reflects the melting of sea ice during the austral spring, allowing sunlight to reach the nutrientrich surface ocean waters. Additionally, the input of fresh 
meltwater increases the upper ocean stratification which then leads to strong phytoplankton blooms. These blooms are commonly linked to Fe inputs from sea ice, upwelling and resuspended coastal sediments, with recent work also considering icebergs (Lancelot et al., 2009). Only in the Amundsen Sea (Gerringa et al., 2012) and along the Antarctic Peninsula (Dierssen et al., 2002) has the possibility of a glacial meltwater influence been suggested. The dust-only simulation (A) does capture these spring blooms to some degree (Fig. 5). However, simulations including icebergs and/or subglacial meltwaters (B-E) produce considerably higher spring PP (c, $10^{3} \mathrm{mg} \mathrm{C} \mathrm{m}^{-2} \mathrm{~d}^{-1}$ ) which is closer to measured values around the Antarctic coast (Smith et al., 1996, 1998; Arrigo et al., 2008; Westwood et al., 2010). This suggests that the ice-sheet-derived iron may be important for the spring blooms observed in the coastal SO.

\section{Summary and conclusions}

Model results presented here suggest that subglacial meltwaters may constitute a significant additional source of bioavailable iron to the SO, supplementing more well studied iceberg sources. The impact of the glacial iron flux may be large, extending across much of the SO due to the redistribution of the iron by ocean circulation. However, our results are likely an upper bound of the relative impact of glacial sources on primary production as we do not include other sources (e.g. sediments, hydrothermal sources) of iron in the model. Increased surface melting has already been observed in some marginal areas of Antarctica, most notably the Antarctic Peninsula (Vaughan, 2006). Enhanced basal melting of ice shelves and ice-shelf shrinkage has also been reported across a number of Antarctic marginal sectors (Pritchard et al., 2012). Any significant change in iron fluxes associated with ice sheet mass balance change may influence the strength of the $\mathrm{SO}$ biological pump, and potentially influence atmospheric $\mathrm{CO}_{2}$ drawdown via fertilisation effects. Refinement of model predictions will be enhanced significantly by drilling campaigns to the ice sheet bed and sub-ice shelf waters, which will enable iron concentrations in subglacial meltwaters to be better constrained.

\section{The Supplement related to this article is available online at doi:10.5194/bg-11-2635-2014-supplement.}

Acknowledgements. We acknowledge support from the following sources: Philip Leverhulme Prize and a Leverhulme Research Fellowship to J. L. Wadham and Leverhulme grant F/00182/BY to Tranter, the latter providing support to R. Death as PDRA. A. Ridgwell is supported by a Royal Society Fellowship and F. Monteiro by Marie Curie Intra European Fellowship within the 7th European Community Framework Programme and NERC
Fellowship NE/J019062/1. This research used data provided by the Ocean Drilling Program (ODP). ODP is sponsored by the US National Science Foundation (NSF) and participating countries under management of Joint Oceanographic Institutions (JOI), Inc. We would also like to thank Alessandro Tagliabue for providing the Southern Ocean observational iron data set.

Edited by: K. Fennel

\section{References}

Anderson, J. B., Domack, E. W., and Kurtz, D. D.: Observations of Sediment-Laden Icebergs in Antarctic Waters - Implications to Glacial Erosion and Transport, J. Glaciol., 25, 387-396, 1980.

Arrigo, K. R., van Dijken, G. L., and Bushinsky, S.: Primary production in the Southern Ocean, 1997-2006, J. Geophys. Res., 113, C08004, doi:10.1029/2007jc004551, 2008.

Bhatia, M. P., Kujawinski, E. B., Das, S. B., Breier, C. F., Henderson, P. B., and Charette, M. A.: Greenland meltwater as a significant and potentially bioavailable source of iron to the ocean, Nat Geosci., 6, 503-503, 2013.

Bigg, G. R., Wadley, M. R., Stevens, D. P., and Johnson, J. A.: Modelling the dynamics and thermodynamics of icebergs, Cold. Reg. Sci. Technol., 26, 113-135, 1997.

Boyd, P. W., Mackie, D. S., and Hunter, K. A.: Aerosol iron deposition to the surface ocean - Modes of iron supply and biological responses, Mar. Chem., 120, 128-143, 2010.

Christner, B. C., Royston-Bishop, G., Foreman, C. M., Arnold, B. R., Tranter, M., Welch, K. A., Lyons, W. B., Tsapin, A. I., Studinger, M., and Priscu, J. C.: Limnological conditions in Subglacial Lake Vostok, Antarctica, Limnol. Oceanogr., 51, 24852501, 2006.

Conkright, M. E., Garcia, H. E., O'Brien, T. D., Locarnini, R. A., Boyer, T. P., Stephens, C., and Antonov, J. I.: Nutrients, in: World Ocean Atlas 2001, 2002.

Demidov, A. B., Vedernikov, V. I., and Sheberstov, S. V.: Spatiotemporal variability of chlorophyll a in the Altantic and Indian sectors of the Southern Ocean during February-April of 2000 according to satellite and expeditionary data, Oceanology, 47, 507518, 2007.

Dierssen, H. M., Smith, R. C., and Vernet, M.: Glacial meltwater dynamics in coastal waters west of the Antarctic peninsula, Proc. Natl. Ac. Sci., 99, 1790-1795, 2002.

Dowdeswell, J. A. and Dowdeswell, E. K.: Debris in Icebergs and Rates of Glaci-Marine Sedimentation - Observations from Spitsbergen and a Simple-Model, J. Geol., 97, 221-231, 1989.

Dowdeswell, J. A., Maslin, M. A., Andrews, J. T., and Mccave, I. N.: Iceberg Production, Debris Rafting, and the Extent and Thickness of Heinrich Layers (H-1, H-2) in North-Atlantic Sediments, Geology, 23, 301-304, 1995.

Dutkiewicz, S., Follows, M. J., and Parekh, P.: Interactions of the iron and phosphorus cycles: A three-dimensional model study, Global Biogeochem. Cy., 19, GB1021, doi:10.1029/2004GB002342, 2005.

Edwards, R. and Sedwick, P.: Iron in East Antarctic snow: Implications for atmospheric iron deposition and algal production in Antarctic waters, Geophys. Res. Lett., 28, 3907-3910, 2001.

Elrod, V. A., Berelson, W. M., Coale, K. H., and Johnson, K. S.: The flux of iron from continental shelf sediments: A miss- 
ing source for global budgets, Geophys. Res. Lett., 31, L12307, doi:10.1029/2004g1020216, 2004.

Follows, M. J., Dutkiewicz, S., Grant, S., and Chisholm, S. W.: Emergent Biogeography of Microbial Communities in a Model Ocean, Science, 315, 1843-1846, 2007.

Fricker, H. A., Scambos, T., Bindschadler, R., and Padman, L.: An active subglacial water system in West Antarctica mapped from space, Science, 315, 1544-1548, 2007.

Gerringa, L. J. A., Alderkamp, A. C., Laan, P., Thuroczy, C. E., De Baar, H. J. W., Mills, M. M., van Dijken, G. L., van Haren, H., and Arrigo, K. R.: Iron from melting glaciers fuels the phytoplankton blooms in Amundsen Sea (Southern Ocean): Iron biogeochemistry, Deep-Sea Res. Pt. II, 71/76, 16-31, 2012.

Gladish, C. V., Holland, D. M., Holland, P. R., and Price, S. F.: Iceshelf basal channels in a coupled ice/ocean model, J. Glaciol., 58, 1227-1244, 2012.

Gladstone, R. M., Bigg, G. R., and Nicholls, K. W.: Iceberg trajectory modeling and meltwater injection in the Southern Ocean, J. Geophys. Res.-Oceans, 106, 19903-19915, 2001.

Jickells, T. D., An, Z. S., Andersen, K. K., Baker, A. R., Bergametti, G., Brooks, N., Cao, J. J., Boyd, P. W., Duce, R. A., Hunter, K. A., Kawahata, H., Kubilay, N., laRoche, J., Liss, P. S., Mahowald, N., Prospero, J. M., Ridgwell, A. J., Tegen, I., and Torres, R.: Global iron connections between desert dust, ocean biogeochemistry, and climate, Science, 308, 67-71, 2005.

Lancelot, C., de Montety, A., Goosse, H., Becquevort, S., Schoemann, V., Pasquer, B., and Vancoppenolle, M.: Spatial distribution of the iron supply to phytoplankton in the Southern Ocean: a model study, Biogeosciences, 6, 2861-2878, doi:10.5194/bg-62861-2009, 2009.

Le Brocq, A. M., Bentley, M. J., Hubbard, A., Fogwill, C. J., Sugden, D. E., and Whitehouse, P. L.: Reconstructing the Last Glacial Maximum ice sheet in the Weddell Sea embayment, Antarctica, using numerical modelling constrained by field evidence, Quaternary Sci. Rev., 30, 2422-2432, 2011.

Le Brocq, A. M., Ross, N., Griggs, J. A., Bingham, R. G., Corr, H. F. J., Ferraccioli, F., Jenkins, A., Jordan, T. A., Payne, A. J., Rippin, D. M., and Siegert, M. J.: Evidence from ice shelves for channelized meltwater flow beneath the Antarctic Ice Sheet, Nature Geosci., 6, 945-948, 2013.

Lythe, M. B., Vaughan, D. G., and Consortium, B.: BEDMAP: A new ice thickness and subglacial topographic model of Antarctica, J. Geophys. Res.-Sol. Ea., 106, 11335-11351, 2001.

Mahowald, N. M., Baker, A. R., Bergametti, G., Brooks, N., Duce, R. A., Jickells, T. D., Kubilay, N., Prospero, J. M., and Tegen, I.: Atmospheric global dust cycle and iron inputs to the ocean, Global Biogeochem. Cy., 19, Gb4025, doi:10.1029/2004gb002402, 2005 .

Mahowald, N. M., Engelstaedter, S., Luo, C., Sealy, A., Artaxo, P., Benitez-Nelson, C., Bonnet, S., Chen, Y., Chuang, P. Y., Cohen, D. D., Dulac, F., Herut, B., Johansen, A. M., Kubilay, N., Losno, R., Maenhaut, W., Paytan, A., Prospero, J. A., Shank, L. M., and Siefert, R. L.: Atmospheric Iron Deposition: Global Distribution, Variability, and Human Perturbations, Annu. Rev. Mar. Sci., 1, 245-278, 2009.

Martin, J. H.: Glacial-Interglacial $\mathrm{CO}_{2}$ Change: The Iron Hypothesis, Paleoceanography, 5, 1-13, 1990.
Martin, T. and Adcroft, A.: Parameterizing the fresh-water flux from land ice to ocean with interactive icebergs in a coupled climate model, Ocean Model, 34, 111-124, 2010.

Monteiro, F. M., Follows, M. J., and Dutkiewicz, S.: Distribution of diverse nitrogen fixers in the global ocean, Global Biogeochem. Cy., 24, GB3017, doi:10.1029/2009gb003731, 2010.

Moore, J. K. and Abbott, M. R.: Phytoplankton chlorophyll distributions and primary production in the Southern Ocean, J. Geophys. Res., 105, 28709-28722, 2000.

Moore, J. K. and Braucher, O.: Sedimentary and mineral dust sources of dissolved iron to the world ocean, Biogeosciences, 5 , 631-656, doi:10.5194/bg-5-631-2008, 2008.

Parekh, P., Follows, M. J., and Boyle, E.: Modeling the global ocean iron cycle, Global Biogeochem. Cy., 18, Gb1002, doi:10.1029/2003gb002061, 2004.

Parekh, P., Follows, M. J., and Boyle, E. A.: Decoupling of iron and phosphate in the global ocean, Global Biogeochem. Cy., 19, Gb2020, doi:10.1029/2004gb002280, 2005.

Pattyn, F.: Antarctic subglacial conditions inferred from a hybrid ice sheet/ice stream model, Earth Planet. Sc. Lett., 295, 451-461, 2010.

Pritchard, H. D., Ligtenberg, S. R. M., Fricker, H. A., Vaughan, D. G., van den Broeke, M. R., and Padman, L.: Antarctic ice-sheet loss driven by basal melting of ice shelves, Nature, 484, 502-505, 2012.

Raiswell, R.: Iron Transport from the Continents to the Open Ocean: The Aging-Rejuvenation Cycle, Elements, 7, 101-106, 2011.

Raiswell, R. and Canfield, D. E.: The Iron Biogeochemical Cycle Past and Present, Geochem. Perspect, 1, 1-186, 2012.

Raiswell, R., Benning, L. G., Tranter, M., and Tulaczyk, S.: Bioavailable iron in the Southern Ocean: the significance of the iceberg conveyor belt, Geochem Trans., 7, 1-9, 2008.

Raiswell, R., Benning, L. G., Davidson, L., Tranter, M., and Tulaczyk, S.: Schwertmannite in wet, acid, and oxic microenvironments beneath polar and polythermal glaciers, Geology, 37, 431434, 2009.

Rutt, I. C., Hagdorn, M., Hulton, N. R. J., and Payne, A. J.: The Glimmer community ice sheet model, J Geophys Res-Earth, 114, F02004, doi:10.1029/2008jf001015, 2009.

Sarmiento, J. L. and Orr, J. C.: 3-Dimensional Simulations of the Impact of Southern-Ocean Nutrient Depletion on Atmospheric $\mathrm{CO}_{2}$ and Ocean Chemistry, Limnol. Oceanogr., 36, 1928-1950, 1991.

Schwarz, J. N. and Schodlok, M. P.: Impact of drifting icebergs on surface phytoplankton biomass in the Southern Ocean: Ocean colour remote sensing and in situ iceberg tracking, Deep-Sea Res. Pt. I, 56, 1727-1741, 2009.

Shaw, T. J., Raiswell, R., Hexel, C. R., Vu, H. P., Moore, W. S., Dudgeon, R., and Smith, K. L.: Input, composition, and potential impact of terrigenous material from free-drifting icebergs in the Weddell Sea, Deep-Sea Res. Pt. II, 58, 1376-1383, 2011.

Sigman, D. M. and Boyle, E. A.: Glacial/interglacial variations in atmospheric carbon dioxide, Nature, 407, 859-869, 2000.

Skidmore, M., Tranter, M., Tulaczyk, S., and Lanoil, B.: Hydrochemistry of ice stream beds - evaporitic or microbial effects?, Hydrol. Process., 24, 517-523, 2010.

Smith, K. L., Sherman, A. D., Shaw, T. J., Murray, A. E., Vernet, M., and Cefarelli, A. O.: Carbon export associated with free-drifting 
icebergs in the Southern Ocean, Deep-Sea Res. Pt. II, 58, 14851496, 2011.

Smith, R. C., Baker, K. S., Byers, M. L., and Stammerjohn, S. E.: Primary productivity of the Palmer Long Term Ecological Research area and the Southern Ocean, J. Marine Syst., 17, 245259, 1998

Smith, W. O. and Nelson, D. M.: Phytoplankton Growth and New Production in the Weddell Sea Marginal Ice-Zone in the Austral Spring and Autumn, Limnol. Oceanogr., 35, 809-821, 1990.

Smith, W. O., Jr., Nelson, D. M., DiTullio, G. R., and Leventer, A. R.: Temporal and spatial patterns in the Ross Sea: Phytoplankton biomass, elemental composition, productivity and growth rates, J. Geophys. Res., 101, 18455-18465, 1996.

Statham, P. J., Skidmore, M., and Tranter, M.: Inputs of glacially derived dissolved and colloidal iron to the coastal ocean and implications for primary productivity, Global Biogeochem. Cy., 22, Gb3013, doi:10.1029/2007gb003106, 2008.

Syvitski, J. P. M., Andrews, J. T., and Dowdeswell, J. A.: Sediment deposition in an iceberg-dominated glacimarine environment, East Greenland: Basin fill implications, Glob. Planet. Change, 12, 251-270, 1996.

Tagliabue, A., Bopp, L., and Aumont, O.: Evaluating the importance of atmospheric and sedimentary iron sources to Southern Ocean biogeochemistry, Geophys. Res. Lett., 36, L13601, doi:10.1029/2009g1038914, 2009.

Tagliabue, A., Bopp, L., Dutay, J. C., Bowie, A. R., Chever, F., JeanBaptiste, P., Bucciarelli, E., Lannuzel, D., Remenyi, T., Sarthou, G., Aumont, O., Gehlen, M., and Jeandel, C.: Hydrothermal contribution to the oceanic dissolved iron inventory, Nature Geosci., 3, 252-256, 2010.
Tagliabue, A., Mtshali, T., Aumont, O., Bowie, A. R., Klunder, M. B., Roychoudhury, A. N., and Swart, S.: A global compilation of dissolved iron measurements: focus on distributions and processes in the Southern Ocean, Biogeosciences, 9, 2333-2349, doi:10.5194/bg-9-2333-2012, 2012.

Tagliabue, A., Aumont, O., and Bopp, L.: The impact of different external sources of iron on the global carbon cycle, Geophys. Res. Lett., 41, 920-926, 2014.

Vaughan, D. G.: Recent trends in melting conditions on the Antarctic Peninsula and their implications for ice-sheet mass balance and sea level, Arct. Antarct Alp. Res., 38, 147-152, 2006.

Wadham, J., Death, R., Monteiro, F. M., Tranter, M., Ridgwell, A J., and Raiswell, R.: The role of the Antarctic Ice Sheet in Global Biogeochemical Cycles, Royal Transactions of the Society of Edinburgh (ISAES proceedings), 104, 1-12, 2013.

Wadham, J. L., Tranter, M., Skidmore, M., Hodson, A. J., Priscu, J., Lyons, W. B., Sharp, M., Wynn, P., and Jackson, M.: Biogeochemical weathering under ice: Size matters, Global Biogeochem. Cy., 24, GB3025, doi:0.1029/2009gb003688, 2010.

Westwood, K. J., Griffiths, F. B., Meiners, K. M., and Williams, G. D.: Primary productivity off the Antarctic coast from 30 degrees80 degrees E; BROKE-West survey, 2006, Deep-Sea Res. Pt. II, 57, 794-814, 2010.

Wingham, D. J., Siegert, M. J., Shepherd, A., and Muir, A. S.: Rapid discharge connects Antarctic subglacial lakes, Nature, 440, 1033-1036, 2006.

Wunsch, C. and Heimbach, P.: Practical global oceanic state estimation, Physica D, 230, 197-208, 2007. 